\title{
MODIFICATIONS IN THE ROOT SYSTEM, GAS EXCHANGES AND PRODUCTIVITY OF SORGHUM HYBRIDS CULTIVATED UNDER WATER DEFICIT
}

\author{
EDER MARCOS SILVA ${ }^{1}$, PAULO CESAR MAGALHÃES ${ }^{2}$, EVARISTO MAURO CASTRO ${ }^{1}$, \\ RONIEL GERALDO ÁVILA ${ }^{1}$ and LORENA GABRIELA ALMEIDA ${ }^{1}$
}

\begin{abstract}
${ }^{1}$ Universidade Federal de Lavras, Caixa Postal: 3037 CEP: 37200-000, Lavras, MG, Brasil
edermarcosbot@hotmail.com; evaristomcastro@gmail.com; ronielgeraldo@yahoo.com; lorenagabrielalg@hotmail.com ${ }^{2}$ Embrapa Milho e Sorgo, Rodovia MG-424, Km 45 Caixa Postal: 285 or 151 CEP: 35701-970, Sete Lagoas, MG, Brasil paulo.magalhaes@embrapa.br
\end{abstract}

Revista Brasileira de Milho e Sorgo, v.17, n.3, p. 380-389, 2018

\begin{abstract}
This study associated data of performance, gas exchange and morphometric analysis of the root system using the WinRhizo software. The main objective was to verify how the modifications in the root system contribute to maintain the photosynthetic rates and productivity in sorghum hybrids divergent regarding tolerance to water deficit. The 1G 282 tolerant hybrid presented higher tolerance to desiccation of the leaves, higher grain productivity (68.33\%) and maintained its photosynthetic rate 2.13 times higher compared to the sensitive BRS 332 during the water deficit. Both hybrids presented responses related to desiccation prevention, characterized by modifications of the root system that are capable to benefit absorption of water and nutrients under stress. Besides, 1G 282 showed more developed and responsive root system, especially due to a higher superficial area of very fine roots (42.67\%), volume of fine roots $(36.90 \%)$ and very fine roots (53.18\%) under water deficit when compared to the sensitive BRS 332 at the same conditions.
\end{abstract}

Keywords: Sorghum bicolor, roots, WinRhizo, photosynthesis.

\section{MODIFICAÇÕES DO SISTEMA RADICULAR, TROCAS GASOSAS E PRODUTIVIDADE EM HÍBRIDOS DE SORGO CULTIVADOS SOB DÉFICIT HÍDRICO}

\begin{abstract}
RESUMO - O estudo em questão associou dados de rendimento, trocas gasosas e morfometria do sistema radicular utilizando o software WinRhizo. O principal objetivo foi verificar como modificações do sistema radicular contribuem para a manutenção da taxa fotossintética e produtividade em híbridos de sorgo divergentes para tolerância ao déficit hídrico (WD), sendo um tolerante (1G 282) e outro sensível (BRS 332). O híbrido tolerante $1 \mathrm{G} 282$ apresentou maior tolerância à desidratação do tecido foliar, além de manter uma taxa fotossintética 2,13 vezes maior e maior rendimento de grãos (68,33\%) em relação ao sensível BRS 332 durante o WD. Ambos os híbridos apresentaram respostas de prevenção à seca, caracterizada por modificações do sistema radicular capazes de favorecer a absorção de água na condição de estresse. No entanto, $1 \mathrm{G} 282$ demonstrou possuir um sistema radicular mais desenvolvido e responsivo, especialmente por exibir maior área superficial de raízes muito finas $(42,67 \%)$ e volume de raízes finas $(36,90 \%)$ e muito finas $(53,18 \%)$ em condição de WD, quando comparado com o sensível BRS 332 nas mesmas condições de cultivo.
\end{abstract}

Palavras-chave: Sorghum bicolor, raízes, WinRhizo, fotossíntese. 
Production and quality of food might experience great impacts in a near future, as the climate changes and global warming can modify the patterns of precipitation and, consequently, expand extreme climate events like droughts (Intergovernmental Panel on Climate Change, 2014). With its effects enhanced by climate changes, drought is considered a limiting factor for food security (Farooq et al., 2009; Anjum et al., 2011). Tropical and developing countries like Brazil will be possibly more affected by the impacts of extreme events such as drought (Intergovernmental Panel on Climate Change, 2014). Thus, it's important to search crops resistant to dry environments (Borrell et al., 2014), capable to maintain high productivity even under water deficit, thus enabling food production, especially in the arid and semi-arid tropics (Hamza et al., 2016).

Sorghum (Sorghum bicolor (Moench) L.) has its origins in Africa and is considered one of the crops most adapted to drought (Pennizi et al., 2009). Despite been used in human feeding in various countries in Africa and Asia (Paiva et al., 2017), in Brazil this grain is mainly used as raw material for the production of cattle ration and ethanol production (Dutra et al., 2013). Genetic and evolution characteristics with different morphophysiological mechanisms make this species highly adapted to drought (Paterson et al., 2009).

One of the possible strategies used by plants in response to water deficit (WD) is the evasion to drought (Fang \& Xiong, 2015). This strategy aims to maintain the high water potential in all the plant tissues, guaranteed by the maximization of the access to water or by the reduction of the loss by transpiration (Luo, 2010). As the roots are the only source for acquiring water on the soil by these plants, growing, density, proliferation and size are the fundamental responses of the plants to drought stress (Fang \& Xiong, 2015). A higher effort of plant in the development of the root system can represent an enhancing on water absorption, maintenance of the photosynthetic activity and plantation production (Lavinsky et al., 2016).

These responses are possible because the root system of many plants present a plastic and responsive morphology, which allows them to adjust to enhance water exploitation and absorption from the soil even in environmental adverse conditions (Armengaud et al., 2009). In a general sense, the acclimation capacity of plants to different stress conditions is possible due to phenotypic plasticity (Bassirirad, 2000). Phenotypic plasticity has been rarely studied in relation to strategies of drought tolerance in sorghum (Magalhães et al., 2016).

Tracing the behavior of morphologic characteristics of the root systems in drought conditions (WD) represents an important bottleneck to understand the responses of different genotypes to this particular stress. Besides, it makes possible the search for new markers that are capable to subsidize the selection to drought tolerance (Lavinsky et al., 2016). In this context, the use of tools like "WinRhizo" software (Magalhães et al., 2016) to track morphometric characteristics of the root system will be an important strategy for genotypic evaluation (Lavinsky et al., 2016).

This study combined evaluations of productivity components, morphometric characteristics of the root system and gas exchange of sorghum hybrids cultivated under different water levels in the soil during the period before flowering. The aim of this study was to understand how the modifications in the root system can contribute to higher photosynthetic 
rates and productivity in hybrids contrasting for drought tolerance.

\section{Material and Methods}

The experiment was conducted in a greenhouse of Embrapa Milho e Sorgo, Sete Lagoas municipality, Minas Gerais state, Brazil (19 $28^{\prime} \mathrm{S}, 4^{\circ} 15^{\prime} 08^{\prime \prime} \mathrm{W}$, $732 \mathrm{~m}$ altitude). The plant material consisted of two sorghum hybrids (Sorghum bicolor L. Moench), 1G 282 (tolerant) and BRS 322 (sensitive). A completely randomized design in a factorial $2 \times 2$ scheme was used with two water conditions, two hybrids and six replications.

Plants were cultivated in plastic pots containing 20kg of Red Latosoil Distrophic Typic and chemical analyzes of the soil were performed with subsequent fertilizations. Water was daily monitored from 9 am to $3 \mathrm{pm}$ using humidity sensors model GB Reader N1535 (Measurement Engineering, Australia) installed in the center of each pot. The sensors can monitor the water tension in the soil since they were coupled to digital indicators based on electric current. Irrigation in pots was performed based on the readings of the sensors, supplying water until field capacity during the period before the stress. During the assay, all the phytosanitary and cultural management were performed according to sorghum standard management demand.

During the stage before flowering, half the plants of each treatment were submitted to WD conditions, and the other half remained daily irrigated aiming to maintain soil humidity to field capacity (FC), with water tension in the soil $-18 \mathrm{kPa}$. The WD was reached with the application of $50 \%$ of the water available until water tension reaches $-138 \mathrm{kPa}$ in the soil. After 12 days under these conditions, the leaf water potential at midday ( $\Psi \mathrm{md}$ ) was determined using a Scholander pression bomb. Gas exchange rates were obtained using an infra-red gas analyzer (IRGA-Infrared Gas Analyzer) model LI 6400 (LICOR, 86 Lincoln, NE, EUA). Maximum quantum efficiency of photosystem II (Fv/Fm) was determined using a fluorimeter with pulse modulated amplitude (Plant Efficiency Analyzer, Hansatech Instruments King's Lynn, United Kingdom).

After the stress period the number of leaves and plant height were evaluated for each plant. Plant height was obtained using a graduated ruler. At the end of the cycle, panicles length, diameter and the number of fertile ramifications by panicle were determined. After these measurements, plants were partitioned in three parts: stalk and leaves, roots and reproductive parts and oven-dried at $70^{\circ} \mathrm{C}$ during $72 \mathrm{~h}$. The dry mass of panicles, grain biomass, 100 grain weight and root biomass were determined. The HI (weight of the dry grain/total dry biomass) was obtained using the total dry biomass.

The entire root system was collected to perform the morphometric analyzes, using five replications per treatment. WinRhizo software (WinRhizo Pro, Regent Inc. Instr., Canada) was used to the morphometric evaluations of the root system, where the volume and area of the superficial roots were determined by classes of diameter, as follows: very fine roots $(\varnothing<$ to $0,5 \mathrm{~mm})$, fine roots $(>0,5 \varnothing<2,0 \mathrm{~mm})$ and thick roots (Ø> 2,0 mm) (Magalhães et al., 2016).

The experimental unity consisted of a pot containing one plant, six replications per treatment (5 replications for the morphometric evaluation of the root system). Data was subjected to preliminary statistical analyzes to adequacy or not to the variance analyze (ANOVA). The means were tested by ScottKnott test at $5 \%$ probability. 


\section{Results and Discussion}

At the end of the stress period, a significant reduction of leaf water potential at midday ( $\Psi \mathrm{md}$ ) was observed in the stressed hybrids (WD) compared to the controls at FC. On the other hand, the sensitive hybrid BRS 332 presented an accentuated decrease compared to the tolerant $1 \mathrm{G} 282$, in the same conditions (Figure 1).

The results showed that the exposure of the plants to drought stress substantially reduced the $\Psi$ md. In fact, under conditions of low water availability in the soil it is possible to note a decreasing of the Imd that leads to the WD (Lavinsky et al., 2016). Analyzing the $\Psi$ md in maize genotypes after the WD periods, Souza et al. (2013) and Ávila et al. (2016) also observed a significant decrease in the water status of leaves compared to control plants. The authors also verified different water status between tolerant and sensitive genotypes, as in this study. The higher $\Psi$ md showed by the tolerant hybrid $1 \mathrm{G} 282$ suggests the existence of the mechanisms that guaranteed a higher hydration of the leaf tissues during drought events.

Photosynthetic rate (A) and stomatal conductance $\left(\mathrm{g}_{\mathrm{s}}\right)$ were different between the hybrids under FC, with higher values for $1 \mathrm{G} 282$. On the same conditions, the transpiration rate (E) was not statistically different between genotypes (Table 1). The WD condition promoted a significant decrease in $\mathrm{A}, \mathrm{g}_{\mathrm{s}}$ and $\mathrm{E}$ in both hybrids. Tolerant hybrid $1 \mathrm{G}$ 282 was superior under WD conditions. Water deficit caused reduction of $75.51 \%$ in $\mathrm{A}, 81.96 \%$ in $\mathrm{g}_{\mathrm{s}}$ and $83.22 \%$ in $\mathrm{E}$ in the BRS 332; in contrast, the reduction in $1 \mathrm{G} 282$ was 42.39, 51.19 and $37.51 \%$, respectively (Table 1). However, the values for water usage efficiency (A/E) and quantum efficiency of photosystem II $\left(\mathrm{F}_{\mathrm{v}} / \mathrm{F}_{\mathrm{m}}\right)$ did not present significant results in this study.

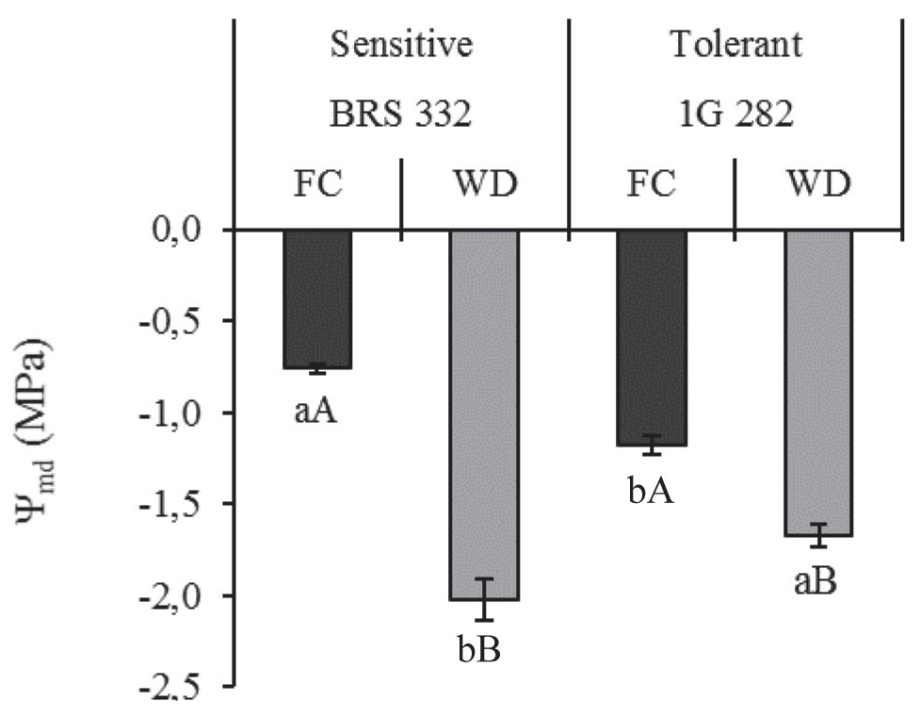

Figure 1. Leaf water potential at midday ( $\Psi \mathrm{md})$ in two sorghum hybrids contrasting for drought tolerance, grown under different water levels in the soil (field capacity - FC, and water deficit - WD).

Means followed by the same letter do not differ statistically. Lowercase letters denote comparisons between hybrids within the same level of water in the soil, and uppercase letters denote comparisons between the water levels in the soil within the same hybrid. Means were compared by Scott-Knott test at $5 \%$ probability. 
Table 1. Variables of gas exchange obtained in two sorghum hybrids contrasting for drought tolerance, grown under different water levels in the soil (field capacity - FC, and water deficit - WD).

\begin{tabular}{ccccc}
\hline \multirow{2}{*}{ Variables } & \multicolumn{3}{c}{ Sensitive } & \multicolumn{2}{c}{ Tolerant } \\
& BRS 332 & FC & WD \\
\cline { 2 - 5 } $\mathrm{A}$ & $36.46 \mathrm{bA}$ & $8.933 \mathrm{bB}$ & $41.76 \mathrm{aA}$ & $24.06 \mathrm{aB}$ \\
$n_{\mathrm{g}}$ & $0.194 \mathrm{bA}$ & $0.035 \mathrm{bB}$ & $0.336 \mathrm{aA}$ & $0.172 \mathrm{aB}$ \\
$\mathrm{E}$ & $4.989 \mathrm{aA}$ & $0.837 \mathrm{bB}$ & $4.806 \mathrm{aA}$ & $3.003 \mathrm{aB}$ \\
$\mathrm{A} / \mathrm{E}$ & $7.320 \mathrm{aA}$ & $10.86 \mathrm{aA}$ & $9.338 \mathrm{aA}$ & $10.02 \mathrm{aA}$ \\
$\mathrm{F}_{\mathrm{v}} / \mathrm{F}_{\mathrm{m}}$ & $0.799 \mathrm{aA}$ & $0.737 \mathrm{aA}$ & $0.807 \mathrm{aA}$ & $0.759 \mathrm{aA}$ \\
\hline
\end{tabular}

Abbreviations: $\mathrm{A}=$ photosynthetic rate $\left(\mu \mathrm{mol} \mathrm{CO} \mathrm{m}^{-2} \mathrm{~s}^{-1}\right) ; \mathrm{g}_{\mathrm{s}}=$ stomatal conductance $\left(\mathrm{mol} \mathrm{H}_{2} \mathrm{O} \mathrm{m}^{-2} \mathrm{~s}^{-1}\right) ; \mathrm{E}=$ transpiration rate $\left(\mathrm{mol} \mathrm{H} \mathrm{O} \mathrm{m}^{-2} \mathrm{~s}^{-1}\right) ; \mathrm{A} / \mathrm{E}=$ efficiency in water use; $\mathrm{F}_{\mathrm{v}} / \mathrm{F}_{\mathrm{m}}=$ maximum efficiency of photosystem II.

Means followed by the same letter do not differ statistically. Lowercase letters denote comparisons between hybrids within the same level of water in the soil, and uppercase letters denote comparisons between the water levels in the soil within the same hybrid. Means were compared by Scott-Knott test at 5\% probability.

The higher water potential of leaves found in the tolerant $1 \mathrm{G} 282$ genotype during drought events contributed to the maintenance of the gas exchanges, ensuring a higher E, gs and consequently a higher entrance of $\mathrm{CO}_{2}$ to the mesophyll. Thus, this water management was extremely important to guarantee a smaller reduction on the photosynthetic rates, since is a common sense that, during drought events, plants that can't make the water management have decreased photosynthesis by reducing stomatal conductance, which characterizes a stomatal limitation (Anjum et al., 2011). These limitations are confirmed by the values of $\mathrm{Fv} / \mathrm{Fm}$, as this variable represents the quantum efficiency of photosystem II (Kalaji et al., 2016). As no differences were observed for this variable, it can be assumed that the reduction on the photosynthetic rates was nor caused by limitation on the biochemical route, but by stomatal closure.

No differences between water conditions and hybrids were observed in A/E. Several studies observed that genotypes more efficient on the water usage are not always more productive (Borba et al., 2017), since the reduction in $\mathrm{g}_{\mathrm{s}}$ limits stomatal
A, and consequently reduces productivity. More relevant in this case is the development of robust and responsive mechanisms that enable water absorption, ensuring a higher leaf water potential, higher $g_{s}$ and photosynthesis.

The $1 \mathrm{G} 282$ was superior at FC and maintained this pattern under stress conditions, while the BRS 332 plants were negatively affected by WD. Besides, drought condition also decreased the number of leaves (LN) in both hybrids. Panicle length (PL) was not different under FC, and was not affected by drought. In the BRS 332, there was a reduction on the panicle diameter in the plants cultivated under WD. In addition, the $1 \mathrm{G} 282$ presented a higher number of fertile ramifications per panicle (NRFP) under FC, while BRS 322 had a decreasing on this variable during the WD (Table 2).

Drought events induce the precocious senescence of the leaves, causing a decrease in the NL (Smit \& Singels, 2006). This process is well characterized in the literature as a mechanism of response of plants under water restrictions (Souza et al., 2013; Borrell et al., 2014). It is important to 
Table 2. Production characters of two sorghum hybrids contrasting for drought tolerance, grown under different water levels in the soil (field capacity - FC, and water deficit - WD).

\begin{tabular}{ccccc}
\hline & \multicolumn{3}{c}{ Sensitive } & \multicolumn{2}{c}{ Tolerant } \\
Variables & FC & WD 282 & FC \\
\cline { 2 - 5 } PH & $1.26 \mathrm{bA}$ & $1.10 \mathrm{bB}$ & $1.41 \mathrm{aA}$ & $1.41 \mathrm{aA}$ \\
LN & $10.0 \mathrm{aA}$ & $6.66 \mathrm{aB}$ & $9.33 \mathrm{aA}$ & $6.66 \mathrm{aB}$ \\
PL & $33.5 \mathrm{aA}$ & $31.0 \mathrm{aA}$ & $37.9 \mathrm{aA}$ & $38.5 \mathrm{aA}$ \\
PD & $9.75 \mathrm{aA}$ & $6.08 \mathrm{bB}$ & $9.16 \mathrm{aA}$ & $8.80 \mathrm{Aa}$ \\
NRFP & $46.3 \mathrm{bA}$ & $24.4 \mathrm{bB}$ & $70.6 \mathrm{aA}$ & $55.0 \mathrm{aB}$ \\
DPB & $154.2 \mathrm{aA}$ & $47.9 \mathrm{bB}$ & $154.5 \mathrm{aA}$ & $122.0 \mathrm{aB}$ \\
DGB & $142.4 \mathrm{aA}$ & $34.1 \mathrm{bB}$ & $138.7 \mathrm{aA}$ & $107.7 \mathrm{aB}$ \\
W100 & $2.36 \mathrm{aA}$ & $1.45 \mathrm{bB}$ & $2.76 \mathrm{aA}$ & $2.85 \mathrm{aA}$ \\
DSB & $90.41 \mathrm{bA}$ & $61.85 \mathrm{bB}$ & $102.12 \mathrm{aA}$ & $97.28 \mathrm{aA}$ \\
TDB & $145.1 \mathrm{aA}$ & $95.44 \mathrm{bB}$ & $143.8 \mathrm{aA}$ & $141.5 \mathrm{aA}$ \\
HI & $0.490 \mathrm{aA}$ & $0.248 \mathrm{bB}$ & $0.483 \mathrm{aA}$ & $0.430 \mathrm{aA}$ \\
\hline
\end{tabular}

Abbreviations: $\mathrm{PH}=$ plant height $(\mathrm{m})$; $\mathrm{LN}=$ number of leaves $\left(\mathrm{N}^{\circ}\right)$; $\mathrm{PL}=$ panicle length $(\mathrm{cm}) ; \mathrm{PD}=$ panicle diameter $(\mathrm{cm})$; NFRP = number of fertile ramifications per panicle $\left(\mathrm{N}^{\circ}\right)$; DPB = dry panicle biomass (g); DGB = dry grain biomass (g); W100 = weight of 100 grains (g); DSB = dry shoot biomass (g); DRB = dry roots biomass (g); TDB = total dry biomass (g); HI = harvest index (g. $\left.\mathrm{g}^{-1}\right)$.

Means followed by the same letter do not differ statistically. Lowercase letters denote comparisons between hybrids within the same level of water in the soil, and uppercase letters denote comparisons between the water levels in the soil within the same hybrid. Means were compared by Scott-Knott test at $5 \%$ probability.

emphasize that a reduction on the NL contributes to a better water management when the water supply in the soil is reduced and insufficient (Farooq et al., 2009). This mechanism was evidenced in the present study, since a reduction pattern on the NL was observed for both hybrids under drought conditions.

Dry panicle biomass (DPB) and dry grain biomass (DGB) were reduced under drought events in both hybrids. However, drought events caused decrease in the DPB (68.92\%) and DGB (76.04\%) in BRS 332, while in $1 \mathrm{G} 282$ the reduction was 21.03 and $22.35 \%$, respectively. Drought affected grain weight (W100) of the BRS 322 plants, reduced by $38.55 \%$. The dry shoot biomass (DSB) of the $1 \mathrm{G}$ 282 plants was higher under FC conditions, and decreased in BRS 332 during WD. The total dry biomass (TDB) was similar in both hybrids, but WD promoted a significant reduction in BRS 332 plants when compared to control. Consequently, under FC conditions, the harvest index (HI) was similar. The HI of BRS 332 plants under WD decreased by $60 \%$ compared to the control under FC. On the other hand, the $\mathrm{HI}$ of the tolerant hybrid was similar to the control under FC (Table 2).

Higher DGB and $\mathrm{PH}$ of the tolerant hybrid can be associated to two physiological factors. The first is related to the source, since $1 \mathrm{G} 282$ presented higher A compared to BRS 332 under WD conditions. This caused higher production of photoassimilates, which are exported and used during the development of the flower organs and grain filling (Araus et al., 2014). The second factor is associated to the HI that represents the efficiency of carbon partition to the 
plant reserves and grains (Magalhães et al., 1998; Souza et al., 2013). This is confirmed by higher PL, PD and NFRP of $1 G 282$ and consequent higher DPB and DGB, compared to the sensitive hybrid under WD.

A higher activity on the drain can be verified observing the W100, as the 1G 282 hybrid did not present alteration in $\mathrm{HI}$ and W100 during the stress condition. This partitioning efficiency of the carbon was also verified in maize genotypes tolerant to drought, because during the drought the $\mathrm{A}$ is reduced and becomes insufficient to support flower development, the plant locates carbon into stalk as a mechanism to guarantee the filling of the grains (Ávila et al., 2016).

The morphometric analyzes of the root images previously scanned with software WinRhizo showed differences in the superficial parts and volume in different diametric classes (Table 3) between the hybrids under FC. The hybrid $1 \mathrm{G} 282$ presented a more developed root system, with higher values for the superficial area of the very fine roots (SAVFR), volume of fine very fine roots (VFRV) and fine roots volume (FRV), compared to BRS 332. The WD condition caused a significant increase of SAVFR, VFRV and FRV values in both hybrids. Tolerant 1G 282 hybrid showed a robust and responsive root system under WD conditions, with higher mean values when compared to BRS 332 cultivated under the same condition (Table 3 ).

Only a few studies evaluated how the root system plasticity is associated to higher photosynthetic rates and yield in plants cultivated under WD conditions (Lavinsky et al., 2016; Magalhães et al., 2016). The difficulty to characterize the morphometry of the roots and also to obtain a complete root system represents the major difficulty for the studies (Manavalan \& Nguyen, 2017). In this context, Magalhães et al. (2011) highlights the utilization of the WinRhizo software as an efficient method that scans the root system and

Table 3. Morphometric characters of roots in two sorghum hybrids contrasting for drought tolerance, grown under different water levels in the soil (field capacity - FC, and water deficit - WD).

\begin{tabular}{|c|c|c|c|c|}
\hline \multirow[t]{2}{*}{ Variables } & \multicolumn{2}{|c|}{$\begin{array}{l}\text { Sensitive } \\
\text { BRS } 332 \\
\end{array}$} & \multicolumn{2}{|c|}{$\begin{array}{c}\text { Tolerant } \\
1 \mathrm{G} 282 \\
\end{array}$} \\
\hline & $\mathrm{FC}$ & WD & $\mathrm{FC}$ & WD \\
\hline SAVFR & $1658.1 \mathrm{bB}$ & $3453.3 \mathrm{bA}$ & $4623.6 \mathrm{aB}$ & $6023.7 \mathrm{aA}$ \\
\hline SAFR & $3987.1 \mathrm{aA}$ & $3921.3 \mathrm{aA}$ & $5934.3 \mathrm{aA}$ & $5304.8 \mathrm{aA}$ \\
\hline SATR & $1399.1 \mathrm{aA}$ & $1387.7 \mathrm{aA}$ & $1350.7 \mathrm{aA}$ & $1268.1 \mathrm{aA}$ \\
\hline TSAR & $7044.4 \mathrm{aA}$ & $8762.4 \mathrm{aA}$ & $11908.6 \mathrm{aA}$ & $12596.8 \mathrm{aA}$ \\
\hline VFRV & $10.915 \mathrm{bB}$ & $21.821 \mathrm{bA}$ & $32.490 \mathrm{aB}$ & $46.612 \mathrm{aA}$ \\
\hline FRV & $77.449 \mathrm{bB}$ & $92.427 \mathrm{bA}$ & $131.46 \mathrm{aB}$ & $146.47 \mathrm{aA}$ \\
\hline TRV & $253.88 \mathrm{aA}$ & $203.97 \mathrm{aA}$ & $219.06 \mathrm{aA}$ & $195.13 \mathrm{aA}$ \\
\hline TVR & $346.90 \mathrm{aA}$ & $324.26 \mathrm{aA}$ & $392.15 \mathrm{aA}$ & $366.69 \mathrm{aA}$ \\
\hline
\end{tabular}

Abbreviations: SAVFR $=$ surface area of very fine roots $\left(\mathrm{cm}^{2}\right)$; SAFR $=$ surface area of fine roots $\left(\mathrm{cm}^{2}\right)$; SATR $=$ surface area of thick roots $\left(\mathrm{cm}^{2}\right)$; TSAR $=$ Total surface area of roots $\left(\mathrm{cm}^{2}\right)$; VFRV $=$ very fine roots volume $\left(\mathrm{cm}^{3}\right) ; \mathrm{FRV}=$ fine roots volume $\left(\mathrm{cm}^{3}\right) ;$ TRV $=$ thick root volume $\left(\mathrm{cm}^{3}\right)$; TVR $=$ total volume of roots $\left(\mathrm{cm}^{3}\right)$.

Means followed by the same letter do not differ statistically. Lowercase letters denote comparisons between hybrids within the same level of water in the soil, and uppercase letters denote comparisons between the water levels in the soil within the same hybrid. Means were compared by Scott-Knott test at 5\% probability. 
enable the tracking of morphological characteristics of roots with different diameters, mainly in controlled plantation conditions.

The scarcity of water and nutrients for plants causes changes on carbon partition patterns, favoring the development of the root system (Brouwer, 1962). The strategy to prevent drought might be reached by the development of a robust and responsive root system, capable to exploit water in deep layers of the soil, or by transpiration (Luo, 2010). Thin and very fine roots are responsible for the majority of water absorbed by the root system, in a way that only plants with conservative characteristics in arid environments can manage its production, thus enhancing water absorption efficiency under WD conditions (Liu et al., 2010).

Both hybrids presented a root system responsive to WD conditions, increasing the variables related to smaller diameters. The $1 \mathrm{G} 282$ tolerant hybrid presented a more developed and responsive root system with higher values of VFRV, FRV, SAVFR in $\mathrm{FC}$ during the WD. In fact, these modifications on the root system induced by drought are largely positively related to the maintenance of the photosynthetic rate and productivity in tolerant genotypes, in crops such as maize and sorghum (Souza et al., 2013; Lavinsky et al., 2016; Ávila et al., 2016).

\section{Conclusions}

The results of this study provide clear evidence about the higher tolerance of the hybrid $1 G 282$ under WD conditions when compared to the BRS 332 hybrid, at the same conditions. This higher tolerance can be related to the existence of a more responsive root system, capable to minimize the water and nutrient absorption during the stress condition.

\section{References}

ANJUM, S. A.; XIE, X. Y.; WANG, L. C.; SALEEM, M. F.; MAN, C.; LEI, W. Morphological, physiological and biochemical responses of plants to drought stress. African Journal of Agricultural Research, v. 6, n. 9, p. 20262032, 2011.

ARAUS, J. L.; SÁNCHEZ, C.; EDMEADES, G. O. Phenotyping maize for adaptation to drought. In: MONNEVEUX, P.; RIBAUT, J. M.; OKONO, A. (Ed.). Drought phenotyping in crops: from theory to practice. Texcoco: CGIAR Generation Challenge Programme, 2014. p. 138-157.

ARMENGAUD, P.; ZAMBAUX, K.; HILLS, A.; SULPICE, R.; PATTISON, R. J.; BLATT, M. R.; AMTMANN, A. EZ-Rhizo: integrated software for the fast and accurate measurement of root system architecture. Plant Journal, v. 57, n. 5, p. 945-956, 2009.

DOI: 10.1111/j.1365-313X.2008.03739.x.

ÁVILA, R. G.; MAGALHÃES, P. C.; ALVARENGA, A. A.; LAVINSKY, A. D. O.; CAMPOS, C. N.; SOUZA, T. C. de; GOMES, J. Drought-tolerant maize genotypes invest in root system and maintain high harvest index during water stress. Revista Brasileira de Milho e Sorgo, Sete Lagoas, v. 15, n. 3, p. 450-460, 2016.

DOI: 10.18512/1980-6477/rbms.v15n3p450-460.

BASSIRIRAD, H. Kinetics of nutrient uptake by roots: responses to global change. The New Phytologist, Cambridge, v. 147, n. 1, p. 155-169, 2000.

DOI: $10.1046 / j .1469-8137.2000 .00682 . x$.

BORBA, M. E. A.; MACIEL, G. M.; FRAGA, J. E.; MACHADO, J. C.; MARQUEZ, G. R.; SILVA, I. G.; ALMEIDA, R. S. Gas exchanges and water use efficiency in the selection of tomato genotypes tolerant to water stress. Genetics and molecular research, Uberlândia, v. 16, n. 2, p. 1-9, 2017. Article gmr16029685.

DOI: $10.4238 / \mathrm{gmr} 16029685$. 
BORRELL, A. K.; MULLET, J. E.; GEORGE-JAEGGLI, B.; OOSTEROM, E. J.; HAMMER, G. L.; KLEIN, P. E.; JORDAN, D. R. Drought adaptation of stay-green sorghum is associated with canopy development, leaf anatomy, root growth, and water uptake. Journal of Experimental Botany, Oxford, v. 65, n. 21, p. 6251-6263, 2014. DOI: $10.1093 / \mathrm{jxb} / \mathrm{eru} 232$.

BROUWER, R. Distribution of dry matter in the plant. Netherlands Journal of Agriculturalscience, Wageningen, v. 10, p. 399-408, 1962.

DUTRA, E. D.; BARBOSA NETO, A. G.; SOUZA, R. B. de; MORAIS JÚNIOR, M. A.; TABOSA, J. N.; MENEZES, R. S. C. Ethanol production from the stem juice of different sweet sorghum cultivars in the State of Pernambuco, Northeast of Brazil. Sugar Tech, v. 15, n. 3, p. 316-321, 2013.

DOI: $10.1007 / \mathrm{s} 12355-013-0240-\mathrm{y}$.

FANG, Y.; XIONG, L. General mechanisms of drought response and their application in drought resistance improvement in plants. Cellular and Molecular Life Sciences, Basel. v. 72, n. 4, p. 673-689, 2015.

DOI: $10.1007 / \mathrm{s} 00018-014-1767-0$.

FAROOQ, M.; WAHID, A.; KOBAYASHI, N.; FUJITA, D.; BASRA, S. M. A. Plant drought stress: effects, mechanisms and management. Agronomy for Sustainable Development, Paris, v. 29, n. 1, p. 185-212, 2009.

DOI: 10.1051/agro:2008021.

HAMZA, N. B.; SHARMA, N.; TRIPATHI, A.; SANANMISHRA, N. MicroRNA expression profiles in response to drought stress in Sorghum bicolor. Gene Expression Patterns, Amsterdam, v. 20, n. 2, p. 88-98, 2016.

DOI: 10.1016/j.gep.2016.01.001.

INTERGOVERNMENTAL PANEL ON CLIMATE CHANGE - IPCC. Fifth assessment report. Cambridge: Cambridge University Press, 2014.

KALAJI, H. M.; JAJOO, A.; OUKARROUM, A.; BRESTIC, M.; ZIVCAK, M.; SAMBORSKA, I. A.; LADLE, R. J. Chlorophyll a fluorescence as a tool to monitor physiological status of plants under abiotic stress conditions. Acta Physiologiae Plantarum, v. 38, n. 4, p. 1-11, 2016. Article 102.

DOI: $10.1007 / \mathrm{s} 11738-016-2113-y$.

LAVINSKY, A. O.; MAGALHÃES, P. C.; DINIZ, M. M.; GOMES JÚNIOR, C. C.; CASTRO, E. M.; ÁVILA, R. Root system traits and its relationship with photosynthesis and productivity in four maize genotypes under drought. Cereal Research Communications, Szeged, v. 44, n. 1, p. 89-97, 2016.

DOI: $10.1556 / 0806.43 .2015 .029$.

LIU, G.; FRESCHER, G. T.; PAN, X.; CORNELISSEN, J. H. C.; LI, Y.; DONG, M. Coordinated variation in leaf and root traits across multiple spatial scales in Chinese semiarid and arid ecosystems. New Phytologist, Cambridge, v. 188 , n. 2, p. 543-553, 2010.

DOI: $10.1111 /$ j.1469-8137.2010.03388.x.

LUO, L. J. Breeding for water-saving and droughtresistance rice (WDR) in China. Journal of Experimental Botany, Oxford, v. 61, n. 13, p. 3509-3517, 2010.

DOI: $10.1093 / \mathrm{jxb} / \mathrm{erq} 185$.

MAGALHÃES, P. C.; DURÃES, F. O. M.; OLIVEIRA, A. C. Efeitos do quebramento do colmo no rendimento de grãos de milho. Ciência e Agrotecnologia, Lavras, v. 22, n. 3, p. 279-289, 1998.

MAGAlHÃes, P. C.; SOUZA, T. C. de; CANTÃO, F. R. O. Early evaluation of root morphology of maize genotypes under phosphorus deficiency. Plant, Soil and Environment, v. 57, n. 3, p. 135-138, 2011.

MAGAlHÃES, P. C.; SOUZA, T. C. de; LAVINSKY, A. O. Phenotypic plasticity of root system and shoots of Sorghum bicolor under different soil water levels during pre-flowering stage. Australian Journal of Crop Science, v. 10, n. 1, p. 81, 2016.

MANAVALAN, L. P.; NGUYEN, H. T. Drought tolerance in crops: physiology to genomics.

In: SHABALA, S. (Ed.). Plant stress physiology. Wallingford: CAB International, 2012. p. 1-23. 
PAIVA, C. L.; QUEIROZ, V. A. V.; SIMEONE, M. L. F.; SCHAFFERT, R. E.; OLIVEIRA, A. C.; SILVA, C. S. Mineral content of sorghum genotypes and the influence of water stress. Food Chemistry, London, v. 214, p. 400-405, 2017. DOI: 10.1016/j.foodchem.2016.07.067.

PATERSON, A. H.; BOWERS, J. E.; BRUGGMANN, R.; DUBCHAK, I.; GRIMWOOD, J.; GUNDLACH, H.; HABERER, G.; HELlSTEN, U.; MITROS, T.; POLIAKOV, A.; SCHMUTZ, J.; SPANNAGL, M.; TANG, H.; WANG, X.; WICKER, T.; BHARTI, A. K.; CHAPMAN, J.; FELTUS, F. A.; GOWIK, U.; GRIGORIEV, I. V.; LYONS, E.; MAHER, C. A.; MARTIS, M.; NARECHANIA, A.; OTILLAR, R. P.; PENNING, B. W.; SALAMOV, A. A.; WANG Y.; ZHANG, L.; CARPITA, N. C.; FREELING, M.; GINGLE, A. R.; HASH, T.; KELLER, B.; KLEIN, P.; KRESOVICH, S.; McCANN, M. C.; MING, R.; PETERSON, D. G.; RAHMAN, M.; WARE, D.; WESTHOFF, P.; MAYER, K. F. X.; MESSING, J.; ROKHSAR, D. S. The Sorghum bicolor genome and the diversification of grasses. Nature, London, v. 457, n. 7229, p. $551,556,2009$.

DOI: $10.1038 /$ nature 07723 .

PENNIZI, E. How sorghum withstands heat and drought. Science, Cambridge, v. 323, n. 5914, p. 573, 2009.

DOI: $10.1126 /$ science.323.5914.573.

SMIT, M. A.; SINGELS, A. The response of sugarcane canopy development to water stress. Field Crops Research, Amsterdam, v. 98, n. 2/3, p. 91-97, 2006.

DOI: $10.1016 /$ j.fcr.2005.12.009.

SOUZA, T. C.; CASTRO, E. M.; MAGALHÃES, P. C.; LINO, L. D. O.; ALVES, E. T.; ALBUQUERQUE, P. E. P. Morphophysiology, morphoanatomy, and grain yield under field conditions for two maize hybrids with contrasting response to drought stress. Acta Physiologiae Plantarum, v. 35, n. 11, p. 3201-3211, 2013.

DOI: $10.1007 / \mathrm{s} 11738-013-1355-1$. 